\title{
Evaluation on the Pathogenesis of Streptococcus agalactiae in Nile Tilapia (Oreochromis niloticus)
}

\author{
Lucienne Garcia Pretto-Giordano ${ }^{1 *}$, Ernst Eckehardt Müller ${ }^{1}$, Julio Cesar de Freitas ${ }^{1}$ and \\ Vanessa Gomes da Silva ${ }^{2}$ \\ ${ }^{1}$ Laboratório de Microbiologia Veterinária e Doenças Infecciosas; Departamento de Medicina Veterinária \\ Preventiva; ${ }^{2}$ Pós-Graduação em Ciência Animal; Universidade Estadual de Londrina; Rodovia Celso Garcia Cid; \\ 86051-990; Londrina - PR - Brasil
}

\begin{abstract}
The pathogenesis of a Streptococcus agalactiae was evaluated in a three-period experiment. Two groups of 40 fishes were intraperitoneally (i.p.) challenged in each experimental period with different infective doses of the pathogen. Doses varied from $1.0 \times 10^{6}$ to $1.5 \times 10^{8}$ CFU/fish. One group of 40 tilapia i.p. injected with tryptic soy broth (TSB) was used as a control group in each period. Mortalities varied from $67.5 \%$ in group 8 (infective dose $1.0 x$ $10^{6}$ CFU/fish) to $90.0 \%$ in group 1 (infective dose $1.5 \times 10^{8}$ CFU/fish). Significant differences in mortalities were found only between group 8 and each of the other groups, except group 5 (infective dose $6.0 \times 10^{6}$ CFU/fish; mortality $75.0 \%$ ). The highest mortality coefficients were observed in days 1-2 after inoculation (accumulated mortality 44.4\%), and a second peak of mortality occurred at days 6-7. Challenged fishes from all the groups showed alterations in behaviour and similar clinical signs. These were anorexia, lethargy, erratic swimming, exophthalmia and ascites. Macroscopically, skin hemorrhage, splenomegaly, hepatomegaly with organ paleness and visceral adherences were observed. S. agalactiae was re-isolated from all the fishes from the experimental groups submitted to bacteriological examination. The illness observed in tilapia naturally infected with $\mathrm{S}$. agalactiae was experimentally reproduced in this study, and the clinical signs produced were similar to those reported from the natural infections.
\end{abstract}

Key words: Streptococcus agalactiae, Nile tilapia (Oreochromis niloticus), clinical signs, and death rate

\section{INTRODUCTION}

Aquaculture is among the fastest growing sectors in the food production industry, with an average annual growth of $8.9 \%$ (Bondad-Reantaso, et al. $2005)$. In the $1950 \mathrm{~s}$, the production of the fishes was approximately one million tons, and in 2004, it reached 59.4 million. The greatest average annual growth - of $21.3 \%$ - occurred in Latin America and in the Caribbean region, which were responsible for only $2.3 \%$ of the world production (FAO, 2006).
In 2004, Brazil produced 177,518 tons of fresh water fishes, from which 69,078 were tilapia. Brazil was classified as the $7^{\text {th }}$ largest producer of tilapia in the world (FAO, 2006). According to statistics Ibama (2005), the state of Paraná produced 11,921 tons of tilapia in 2004. The growth in global aquaculture, associated to the globalization of commerce, introduction of new species and intensive handling systems, among others, have increased sanitary problems and the appearance of emergent diseases (BondadReantaso et al., 2005). Among the bacterial

\footnotetext{
*Author for correspondence: lgiordano@uel.br
} 
diseases, streptococci have increased with the intensive farming of fresh water fishes. Streptococcus spp. is considered the main pathogen present in different fish species.

Streptococcus agalactiae is the most commonly found species in hot climate, being associated to different fresh water, marine and estuary fish species (Evans et al., 2002). First reports of streptococci in the fishes were from Hoshina et al. (1958), in Japan, in cultivated rainbow trout. Since then, infection from this pathogen has been reported in several other fish species (Inglis et al., 1993). S. difficile was first reported by Eldar et al. (1994), in Israel, as a non-hemolytic coccus causing septicemia and meningoencephalitis in tilapia (Oreochromis spp.) and rainbow trout (Oncorhynchus mykiss). Recent studies have shown that $S$. difficile belongs to Lancefield's B group, Ib type, with cellular protein electrophoretic profile indistinguishable from $S$. agalactiae (Vandamme et al., 1997). Kawamura et al. (2005) proposed a re-classification of $S$. difficile in order to unify the terminology, considering $S$. difficile and $S$. agalactiae synonyms. In Brazil, Salvador et al. (2005) isolated Lancefield's group B non-hemolytic Streptococcus spp. from tilapia cultivated in nettanks and earthen ponds in the state of Paraná. Figueiredo et al. (2006) isolated S. agalactiae from tilapia cultivated in net-tanks in the states of Minas Gerais and Espírito Santo.

Eldar et al. (1995) reported the erratic swimming, decrease in appetite, lethargy, exophthalmia with intraocular hemorrhage and opaqueness of cornea, and ascites, in the fishes infected by $S$. difficile. Swimming in circles, uncoordinated movements, and dorsal rigidness are indicators of the compromising of central nervous system. Salvador et al. (2005) observed a high morbidity and mortality in $S$. agalactiae when tilapia were cultivated in net-tanks, which presented erratic and circular swimming, appetite decrease, uni- or bilateral exophthalmia and visceral cavity distension as main clinical signs. Main macroscopical alterations reported by Salvador et al. (2003) were injuries in the skin, fins, branchiae, opacity of the cornea, liquid in visceral cavity, liver and splenomegaly. The intensity of lesions and clinical signs in tilapia depends on factors related to $S$. agalactiae strain, infective dose, amount of water, temperature, biomass and also on handling (Chang and Plumb, 1996).
The objectives of the present study were to evaluate the mortality rate, clinical signs, and macroscopic injuries in Nile tilapia (Oreochromis niloticus) experimentally inoculated with a field sample of $S$. agalactiae in different concentrations.

\section{MATERIALS AND METHODS}

\section{Fish}

For this study, 360 Nile tilapia (O. niloticus) with an average weight of $50 \mathrm{~g}$ (40 to $60 \mathrm{~g}$ ) were used, which were kindly provided by the Pisciculture Station, from the Animal and Vegetal Department, at Londrina State University. These fishes did not present any sign of infection neither by streptococci nor other pathogens. Before the beginning of each experiment, three fishes were randomly necropsied. Cranial kidney and brain were collected for the bacteriological examination, with the objective of verifying if the fishes were free from $S$. agalactiae and others.

\section{Fish handling}

Nine groups of the fishes were made, each with 40 animals. These groups were kept in 500L fiberglass containers with $400 \mathrm{~L}$ water and renewal rate of $3 \mathrm{~L}$ water per minute. The fishes were fed twice a day with extruded ration (FISH ${ }^{\mathrm{TM}} 30 \%$ gross protein, Cooperativa Integrada) in the ratio of 3\% live weight per day. In these conditions, fishes were acclimatized during 10 days before the beginning of the experiments.

\section{Water quality control evaluation}

The containers were filled with semi-artesian well water, with continuous flow and aeration, and cleaning was performed by suction on a daily basis. During the experiment, average concentration of oxygen was $3.8 \pm 0.5 \mathrm{mg} / \mathrm{L}$, temperature $26.0 \pm 0.8^{\circ} \mathrm{C}$, ammonia $0.05 \mathrm{mg} / \mathrm{L}$ and nitrites $0.25 \mathrm{mg} / \mathrm{L}$. Oxygen levels and temperature were measured daily with equipment model YSI 55 (Yellow Spring Instrument, Yellow Springs, OH, USA). Ammonia was measured quarterly by Berthelot reaction (Solaranzo, 1969) and nitrite was quantified by Griess reaction (Aminot and Chaussepied, 1983).

\section{Preparation of inoculum}

$S$. agalactiae (UEL 12) used as inoculum in the experiments was isolated from an outbreak 
characterized by the elevated morbidity and mortality of tilapia in an intensive farming property using net-tanks in the Northern region of Paraná. The isolated strain was aliquoted and stored in liquid nitrogen until its use. One $S$. agalactiae aliquot was inoculated in TSB (Tryptic Soy Broth - Difco Laboratories, Sparks, MD) and incubated at $30^{\circ} \mathrm{C}$ for $48 \mathrm{~h}$. In order to verify the purity of the inoculum, one aliquot from the culture was inoculated in Agar Columbia (Difco Laboratories, Sparks, MD) with an additional 5\% sheep blood (ACS) and incubated at $30^{\circ} \mathrm{C}$ in aerophile atmosphere for $48 \mathrm{~h}$.

For each period in the experiment, a culture with concentration of $1.5 \times 10^{9} \mathrm{CFU} / \mathrm{mL}$ standardized by spectrophotometies (Cintra 5) with wavelength of $540 \mathrm{~nm}$, optical density (OD) of 0.60 , and counting in plates $(\mathrm{CFU} / \mathrm{ml})$ with TSA (Tryptic Soy Agar - Difco Laboratories, Sparks, MD) was prepared. Dilutions in TSB (Tryptic Soy Broth Difco Laboratories, Sparks, MD) were performed from this original concentration for the obtainment of infective doses, confirmed by counting in TSA plates.

\section{Experiment}

The experiment was performed in three different periods. In each period, two infective doses of $S$. agalactiae were analyzed. Challenged fishes were intraperitoneally innoculated (i.p.) with $0.1 \mathrm{~mL}$ bacterial suspension, and those from the control groups with $0.1 \mathrm{~mL}$ i.p. sterile TSB. In the first period (April/2004), groups 1,2 and 3 were inoculated with a bacterial suspension of $1.5 \times 10^{8}$ CFU/fish, $5.0 \times 10^{7}$ CFU/fish and TSB, respectively. In the second period (June/2004), groups 4,5 and 6 were inoculated with the bacterial suspension of $2.0 \times 10^{7} \mathrm{CFU} / \mathrm{fish}, 6.0 \mathrm{x}$ $10^{6} \mathrm{CFU} /$ fish and TSB, respectively. In the third period (August/2005), groups 7, 8, and 9 were inoculated with the bacterial suspension of $1.2 \mathrm{x}$ $10^{8} \mathrm{CFU} / \mathrm{fish}, 1.0 \times 10^{6} \mathrm{CFU} / \mathrm{fish}$ and TSB, respectively. After inoculation, the fishes were monitored twice a day, for a period of 12 days. Daily mortality and main clinical symptoms were recorded. Dead fishes were collected in sterile plastic bags for the necropsy, macroscopic injuries and bacteriological tests.

\section{Collection and analyzes of samples}

In order to collect the biological material, 12 tilapia presenting clinical signs were autopsied in each period. A total of 107 samples were aseptically collected, being 36 from kidney, 32 from brain and the remaining from eye, liver, visceral liquid and heart. The samples were inoculated in ACS and the plates were incubated at $30^{\circ} \mathrm{C}$ during $72 \mathrm{~h}$. The morphology of the colonies and the absence of hemolysis were observed. Those colonies considered typical were submitted to Gram stain, catalase test, esculin, $\mathrm{NaCl} 6.5 \%$ and growth in Methylene Blue Agar. The identification of $S$. agalactiae was performed according to Evans et al. (2002). For the biochemical identification, Api 20 Strep (BioMérieux, France) was used, and for the classification in Lancefield group, Slidex strepto kit (BioMérieux, France) was used.

\section{Statistics}

Absolute and relative frequencies for daily mortality of tilapia per S. agalactiae concentration were verified. In order to compare the mortality rates in each concentration, Chi-Square test with $5 \%$ significance level was used.

\section{RESULTS}

Table 1 presents the mortality of the six inoculation experiments using different $S$. agalactiae infective doses. The mortality ranged from of 67.5 to $90.0 \%$ and the highest mortality was with $1.5 \times 10^{8} \mathrm{CFU} /$ fish. There was no significant difference in the mortality among groups 1, 2, 4, 5 and 7. Group 8, which was inoculated with $1.0 \times 10^{6} \mathrm{CFU} / \mathrm{fish}$, presented mortality of $67.5 \%$, a significant difference when compared to the other groups, with the exception of group 5. In the three control groups, two of 120 (1.67\%) fishes died.

The highest mortality coefficients occurred on the first and second day, 60 (30.3\%) and 28 (14.1\%), respectively, presenting an accumulated mortality of $44.4 \%$. A second mortality peak occurred between the sixth and seventh day, with the death of $23(11.6 \%)$ and $25(12.6 \%)$ fishes, respectively. Until the seventh day, the accumulated mortality was $83.2 \%$.

The fishes from the control groups fed normally and were active during the whole experiment. The fishes from all the groups inoculated with $S$. agalactiae presented alterations in behavior and similar clinical signs. On day 1 after the inoculation, an elevated mortality rate was observed, characterized by sudden death, while the 
majority of the fishes were swimmig lethargic at the bottom of the tank, suffering from alterations in skin color and anorexia. From day 2, a worsening of clinical signs was noticed, including erratic swimming, uni- and bi-lateral exophthalmia, opacity of the cornea, and stretching of visceral cavity. In 36 fishes autopsied, the main injuries were skin hemorrhage, ascites, softening of brain and liver, hepatomegaly and paleness of the organ, splenomegaly and visceral adherence. In all the 107 samples submitted to bacteriological tests, S. agalactiae was isolated, presenting the same morphological, cultural, phenotypical and serological characteristics of the strain used for the experimental inoculation. S. agalactiae was reisolated from the brain, kidney, liver, heart, eye and ascitic fluid. S. agalactiae was not isolated from the fishes in the control groups that died along the experiment.

Table 1 - Mortality of Nile tilapia (Oreochromis niloticus) observed during 12 days after inoculation, in three periods, with different infective doses of Streptococcus agalactiae isolated from tilapia naturally infected, Londrina, Brazil, 2005.

\begin{tabular}{cccccc}
\hline *Group & N Fish & Period & $\begin{array}{c}\text { Inoculum } \\
\text { UFC/fish }\end{array}$ & Total & \% \\
\hline $1^{\text {a }}$ & 40 & April/2004 & $1.5 \times 10^{8}$ & 36 & 90,0 \\
$2^{\text {a }}$ & 40 & April/2004 & $5.0 \times 10^{7}$ & 35 & 87,5 \\
$3^{\mathrm{c}}$ & $\mathbf{4 0}$ & April/2004 & Control & $\mathbf{0}$ & 0 \\
$4^{\mathrm{a}}$ & 40 & June/2004 & $2.0 \times 10^{7}$ & 35 & 87,5 \\
$5^{\text {a,b }}$ & 40 & June/2004 & $6.0 \times 10^{6}$ & 30 & 75,0 \\
$6^{\mathrm{c}}$ & $\mathbf{4 0}$ & June/2004 & Control & $\mathbf{1}$ & 2,5 \\
$7^{\mathrm{a}}$ & 40 & August/2005 & $1.2 \times 10^{8}$ & 35 & 87,5 \\
$8^{\mathrm{b}}$ & 40 & August/2005 & $1.0 \times 10^{6}$ & 27 & 67,5 \\
$9^{\mathrm{c}}$ & $\mathbf{4 0}$ & August/2005 & Control & $\mathbf{1}$ & 2,5 \\
\hline
\end{tabular}

*Different letters indicate significant difference among groups $(\mathrm{P} \leq 0.05)$

\section{DISCUSSION}

Evans et al. (2002) had observed the onset of clinical signs within $24 \mathrm{~h}$ after the inoculation of $S$. agalactiae in the concentration of $1.0 \times 10^{7}$ CFU/fish i.p. and accumulated mortality rate of $60 \%$ after seven days. Mortality rate of $30 \%$ was reported in the first $24 \mathrm{~h}$ after the inoculation of tilapia with $S$. agalactiae at $4.5 \times 10^{6}$ and $5.5 \times$ $10^{2} \mathrm{CFU} /$ fish, with mortality at the end of the experiment of 60 and 50\%, respectively (Evans et al., 2004). Pasnik et al. (2005) observed mortality of 84 to $96 \%$ in the control groups with streptococcic vaccines challenged with $S$. agalactiae $\left(1.89 \times 10^{4}\right.$ and $2.11 \times 10^{4} \mathrm{CFU} /$ fish), respectively. A comparison of the present results (Table 1) with those found in literature, show a sharp difference between the reported mortality coefficients. Several factors, such as the concentration of inoculum, $S$. agalactiae strain type, inoculation manner, observation period after challenge, age and weight of fish, reactivation of pathogenicity, could induce these differences.

In this research, the $S$. agalactiae strain used was not reactivated for inoculation of the fishes in the different experimental groups, justifying the highest concentration of bacteria in the inoculum. However, there were no significant difference between the mortality coefficients from the fishes belonging to groups 1 and 7 (Table 1), performed with intervals of 16 months, using the same $S$. agalactiae strain, kept in liquid nitrogen. Eldar et al. (1995) observed that the virulence of an $S$. difficile strain isolated from the natural infection in tilapia increased after three passages in the fish. $\mathrm{DL}_{50}$ lowered in the rate of five logarithms, from the initial concentration of $10^{7}$ to $10^{2} / \mathrm{CFU}$. Rasheed and Plumb (1984) reactivated the virulence of non-hemolytic Streptococcus sp. belonging to Lancefield group $\mathrm{B}$ and observed mortality of $50 \%$ after $96 \mathrm{~h}$ from i.p. inoculation of $1.4 \times 10^{4} \mathrm{CFU} /$ fish $\left(\mathrm{DL}_{50}\right)$. 
The inoculation route influences the mortality rate of experimentally inoculated fish. Perera et al. (1997) infected the tilapia with $S$. iniae through oral route (inoculation in the intestine through catheter), by immersing the fishes in the bacterial solution and through i.p. injection, and observed a mortality rate of 50,34 and $95 \%$, respectively. McNulty et al. (2003) have shown that S. iniae was able to invade the filamentous epithelium of the gill and cause septicemia. However, a low mortality rate $(13.33 \%)$ was observed when the fishes were experimentally instilled in the gills with $5.0 \times 10^{5} \mathrm{CFU} /$ fish.

Similar clinical signs to those observed in this study were reported by Salvador et al. (2003; 2005), in the Brazilian state of Parana, and also by Figueiredo et al. (2006) in the Brazilian states of Espírito Santo and Minas Gerais, in the tilapia cultivated in the earthen ponds and net-tanks. The authors reported lethargia, anorexia, erratic swimming, uni-or bilateral exophthamia, ascites and high mortality. Similar clinical signs were also observed in naturally infected tilapia in Israel and the USA (Eldar et al., 1995; Plumb, 1999). Clinical signs observed in the fishes experimentally inoculated with $S$. difficile and $S$. agalactiae described in literature were similar to those observed in natural infection (Eldar et al., 1995; Evans et al., 2002; Evans et al., 2004). Similar clinical signs were also observed in tilapia experimentally or naturally infected by $S$. iniae (Perera et al., 1994; Evans et al., 2000; Shelby et al., 2002). Hemorrhagic injuries in the skin, ascites, hepatomegaly and splenomegaly observed in the fishes inoculated in this experiment were compatible with those reported by Salvador et al. (2005) and Figueiredo et al. (2006) in the tilapia naturally infected in Brazil.

\section{CONCLUSIONS}

S. agalactiae strain isolated from the naturally infected tilapia reproduced the illness in the fishes intraperitoneally experimentally inoculated with different infective doses. Clinical signs and macroscopical injuries were similar to those described in natural the infection.

\section{ACKNOWLEDGEMENTS}

The authors would like to thank the Animal and Vegetal Department, of Londrina State University for kindly providing the fish and the Pisciculture Station to perform the experiments and Mauro Caetano Filho and Heitor Frossard Santos for their excellent technical assistance.

\section{RESUMO}

A patogenicidade do $S$. agalactiae foi avaliada experimentalmente em três períodos. Dois grupos de 40 peixes foram inoculados intraperitonealmente (i.p.) em cada período com diferentes doses infectantes do patógeno. As doses variaram de 1,0 x $10^{6}$ a $1,5 \times 10^{8} \mathrm{UFC} /$ peixe. Como controle, um grupo de 40 peixes foi inoculado tryptic soy broth (TSB) via i.p. em cada período. Mortalidades variaram de $67,5 \%$ no grupo 8 (dose infectante $1,0 \times 10^{6}$ UFC/peixe) a 90,0\% no grupo 1 ( dose infectante 1,5 x $10^{8} \mathrm{UFC} /$ peixe). Diferença significativa de mortalidade foi observada somente entre o grupo $8 \mathrm{e}$ os demais grupos, exceto com grupo 5 (dose infectante $6,0 \times 10^{6}$ UFC/peixe - 75,0\% de mortalidade). Os maiores coeficientes de mortalidade foram observados no 1 e $2^{\circ}$ dia após a inoculação (mortalidade acumulada de 44,4\%), e o segundo pico de mortalidade ocorreu no 6 e $7^{\circ}$ dia. Em todos os peixes inoculados foi observada alteração de comportamento e sinais clínicos semelhantes. Anorexia, letargia, natação errática, exoftalmia e ascite. Macroscopicamente, foi observada hemorragia na pele, esplenomegalia, hepatomegalia, palidez dos órgãos e aderências viscerais. $S$. agalactiae foi re-isolado dos peixes submetidos ao exame bacteriológico. A doença observada nas tilápias infectadas naturalmente com essa cepa de $S$. agalactiae foi experimentalmente reproduzida nesse trabalho, e os sinais clínicos foram similares à infecção natural.

\section{REFERENCES}

Aminot, A. and Chaussepied, M. (1983), Manuel des analyses chimiques em milieu Marin. Brest: CNEXO. 
Bondad-Reantaso, M.G.; Subasinghe, R.P.; Arthur, J.R.; Ogawa, K.; Chinabut, S.; Adlard, R.; Tan, Z.and Shariff, M. (2005), Disease and health management in Asian aquaculture. Veterinary Parasitology, 132, 249-272.

Chang, P.H. and Plumb, J.A. (1996), Effects of salinity on Streptococcus infection of Nile tilapia, Oreochromis niloticus. Journal of Applied Aquaculture, 6, 39-45.

Eldar, A., Bejerano, Y. and Bercovier H. (1994), Streptococcus shiloi and Streptococcus difficile: two new streptococcal species causing a meningoencephalitis in fish. Current Microbiology, 28, 139-143.

Eldar, A.; Bejerano, Y; Livoff , A.; Horovitcz, A. and Bercovier, H. (1995), Experimental streptococcal meningo-encephalitis in cultured fish. Veterinary Microbiology, 43, 33-40.

Evans, J.J; Shoemaker, C.A. and Klesius, P.H. (2000), Experimental Streptococcus iniae infection of hybrid striped bass (Morone chrysops $x$ Morone saxatilis) and tilapia (Oreochromis niloticus) by nares inoculation. Aquaculture, 189, 197-210.

Evans, J.J.; Klesius, P.H.; Gilbert, P.M.; Shoemaker, C.A.; Al Sarawi, M.A.; Landsberg, J.; Duremdez R.; $\mathrm{Al}$ Marzouk A. and Al Zenki S. (2002), Characterization of b-hemolytic group B Streptococcus agalactiae in cultured sea bream, Sparus auratus L., and wild mullet, Liza klunzingeri, in Kuwait. Journal of Fish Diseases, 25, 505-513.

Evans, J.J.; Wiedenmayer, A.A.; Klesius, P.H. and Shoemaker, C.A. (2004), Survival of Streptococcus agalactiae from frozen fish following natural and experimental infections. Aquaculture, 233, 15-21.

Figueiredo, H.P.C.; Carneiro, D.O.; Faria, F.C. and Costa, G.M. (2006), Streptococcus agalactiae associado a meningoencefalite e infecção sistêmica em tilápia-do-nilo (Oreochromis niloticus) no Brasil. Arquivo Brasileiro de Medicina Veterinária $e$ Zootecnia, 58, 678-680.

Food and Agriculture Organization of the United Nations. (2006), State of world aquaculture 2006. Rome, 134p. FAO fisheries technical paper, n. 500.

Hoshina, T.; Sano, T. and Morimoto, Y. (1958), A Streptococcus pathogenic to fish. Journal of Tokyo University of Fish, 44, 57-58.

IBAMA - Instituto Brasileiro do Meio Ambiente e dos Recursos Naturais Renováveis (2005). Estatística da pesca 2004: Brasil - grandes regiões e unidades da federação. Boletim do IBAMA, Brasília, DF, p.85.

Inglis, V., Roberts, R.J. and Bromage, N.R. (1993), Streptococcal Infections. In-Bacterial Diseases of fish. New York: Halsted, pp.196-97.

Kawamura, Y.; Itoh, Y.; Mishima, N.; Ohkusu, K.; Kasai, H. and Ezaki, T. (2005), High genetic similarity of Streptococcus agalactiae and Streptococcus difficilis: S. difficilis Eldar et al. 1995 is a later synonym of $\mathrm{S}$. agalactiae Lehmann and Neumann 1896 (Approved Lists 1980). International Journal of Systematic Evolutionary Microbiology, 55, 961-965.
McNulty, S.T; Klesius, P.H.; Shoemaker, C.A. and Evans, J.J. (2003), Streptococcus iniae infection and tissue distribution in hybrid striped bass (Morone chrysops x Morone saxatilis) following inoculation of the gills. Aquaculture, 220, 165-173.

Pasnik, D. J.; Evans, J.J. and Klesius, P.H. (2005), Duration of protective antibodies and correlation with survival in Nile tilapia Oreochromis niloticus following Strepococcus agalactiae vaccination. Diseases of aquatic organisms, 66, 129-134.

Perera, R.P., Collins, M.D., Johnson, S.K. and Lewis, D.H. (1994), Streptococcus iniae associated with mortality of Tilapia nilotica x T. aurea. Journal Aquatic Animal Health, 6, 335-340.

Perera, R.P.; Johnson, S.K. and Lewis, D.H. (1997), Epizootiological aspects of Streptococcus iniae affecting tilapia in Texas. Aquaculture, 152, 25-33.

Plumb, J.A. (1999), Tilapia bacterial diseases. InHealth: maintenance and principal microbial diseases of cultured fishes. Ames: Iowa State University, pp.297-305.

Rasheed, V. and Plumb J.A. (1984), Pathogenicity of a non-hemolytic group B Streptococcus sp. in Gulf killifish (Fundulus grandis Baird and Girard). Aquaculture, 37, 97-105.

Salvador, R; Müller, E.,E.; Leonhardt, J.H.; PrettoGiordano, L.G.; Dias, J.A.; Freitas, J.C. and Moreno, A.M. (2003), Isolamento de Streptococcus spp de tilápia do Nilo (Oreochromis Niloticus) e qualidade da água de tanques rede na Região Norte do Estado do Paraná, Brasil. Semina: Ciências Agrárias, 24, 3542.

Salvador, R.; Müller, E.E.; Freitas, J.C.; Leonhadt, J.H.; Pretto-Giordano, L.G. and Dias, J.A. (2005), Isolation and characterization of Streptococcus spp. group B in Nile tilapia Oreochromis niloticus) reared in hapas nets and earth nurseries in the northern region of Parana State, Brazil. Ciência Rural, 35, 1374-1378.

Shelby, R.A.; Klesius, P.H.; Shoemaker, C.A and Evans, J.J. (2002), Passive immunization of tilapia, Oreochromis niloticus (L.), with anti-Streptococcus iniae whole sera. Journal of fish diseases, 25, 1-6.

Solaranzo, L. (1969), Determiantion of ammonia in natural waters by the phenolhypoclorite method. Limnology Oceanografy, 14, 799-801.

Vandamme, P.; Devriese, L.A.; Pot, B.; Kersters, K. and Melin, P. (1997), Streptococcus difficile is a nonhemolytic Group B, tipe Ib Streptococcus. International Journal of Systematic Bacteriology, 47, 81-85.

Received: November 08, 2007; Revised: June 25, 2008; Accepted: July 08, 2009. 